\title{
Eliminasi Kesenjangan Kualitas SDM Melalui Kebijakan Afirmasi Pendidikan di Jawa Timur
}

\author{
Eliminating Human Resource Disparity Through Educational \\ Affirmative Policy in East Java
}

\author{
Madekhan \\ Sekolah Pascasarjana Universitas Islam Lamongan \\ E-mail korespondensi: madekhan@unisla.ac.id
}

\begin{abstract}
Abstrak
Kesenjangan kualitas sumberdaya manusia antar wilayah merupakan gejala umum pembangunan daerah, tidak terkecuali Jawa Timur. Selain diperlukan penguatan sinergi sumberdaya pemerintah, masyarakat sipil dan sektor swasta, untuk memastikan eliminasi ketertinggalan wilayah pinggiran dengan wilayah pusat, diperlukan pula implementasi kebijakan afirmasi. Tujuan kajian ini untuk memformulasi kebijakan afirmasi pendidikan dalam rangka eliminasi Kesenjangan Kualitas SDM, sesuai kapasitas sumberdaya dan tingkat kewenangan Pemerintah Provinsi Jawa Timur. Melalui metode studi dokumen diperoleh gambaran bahwa kinerja pertumbuhan ekonomi 2019 Jawa timur termasuk tinggi 5,52\%, namun masih diikuti tingginya angka kemiskinan 10,37\%. Rata-rata lama sekolah penduduk masih 8,21 tahun, atau setara kelas dua SMP sederajat. Dari 38 Kabupaten/kota, hanya 5 daerah yang pendapatan per kapitanya lebih tinggi dari per kapita nasional. Berbasis indikator IPM didapati 14 Kabupaten memerlukan kebijakan afirmasi, dan 10 Kabupaten dengan indikator kemiskinan di atas angka 13\%. Hasil kajian menunjukkan bahwa pemerintah Provinsi Jawa Timur memiliki peluang implementasi kebijakan afirmasi pendidikan dalam tiga bentuk: Pertama melalui jalur kebijakan transfer anggaran pada pos belanja Bantuan Keuangan kepada Kabupaten/kota, kedua melalui jalur Bantuan Hibah yang langsung ditransfer ke rekening sekolah, dan ketiga melalui regulasi yang menjamin mutu sekolah di daerah terpencil.
\end{abstract}

Kata kunci: ketimpangan sumber daya manusia, pendidikan, kebijakan afirmatif

\begin{abstract}
Disparity in the quality of human resources among regions is a common symptom of regional development, included East Java. In addition to strenghening synergy between the government, civil society and the private sector, it is necessary to implement affirmative policies. The purpose of this study is to formulate educational affirmative policy in the context of eliminating disparity of human resource quality, according to resource capacity and the level of authority of the Government of East Java Province. Based on documents analysis method, shows that East Java's economic growth performance in 2019 is high, 5.52\%, but it is still followed by a high poverty rate of $10.37 \%$. The means years of school (MYS) of population is still 8.21 years, or equivalent of second grade of junior high school. From 38 regencies, only 5 regions have per capita income higher than the national per capita. Based on HDI indicators found 14 districts need affirmative policy, and using poverty indicators above $13 \%$, there are 10 districts which need affirmative policy. The results of the study show that government of East Java
\end{abstract}




\section{Madekhan: "Eliminasi Kesenjangan Kualitas SDM Melalui Kebijakan Afirmasi Pendidikan di Jawa Timur"}

has prospect to implement the affirmative policy in three forms: First through the Financial Aid expenditure (Bantuan Keuangan) transferred to the district/city account, second through the Grant Aid (Bantuan Hibah) which is directly transferred to school accounts, and the third through regulation of quality assurance for schools in remote area.

Keywords: human resource inequality, education, affirmative policy

\section{Pendahuluan}

Pendidikan bukan tanggung jawab sekolah atau universitas itu sendiri. Bukan hanya siswa dan keluarga mereka, yang menginvestasikan waktu dan uang ke dalam pendidikan. Kita semua - masyarakat - secara kolektif paling tidak menginvestasikan pembayaran pajak kita untuk mensubsidi sekolah dan perguruan tinggi. Konsekuensinya, sekolah dan universitas harus mampu menciptakan inovasi, produktivitas, dan pengembangan sumber daya manusia masyarakat. Semua program harus dirancang untuk perubahan sosial yang positif, dengan mendorong hal-hal seperti partisipasi politik, kesejahteraan sosial, dan kelestarian lingkungan hidup.

Melalui kolaborasinya, lembaga pendidikan kita juga harus mampu mempromosikan keterlibatan dengan komunitas, industri, pemerintah, dan media massa. Kita bersama memotivasi siswa kita untuk menjadi warga negara yang lebih terbuka, bijaksana, dan bertanggung jawab, yang akhirnya siap mengamalkannya di masyarakat. Ketika mereka lulus, mereka akan membawa nilai-nilai kehidupan (living values), dan secara kontinyu membangun lingkungan dan peri kehidupan yang lebih baik (Meents, 2010).

Untuk mencapai idealitas pengembangan sumberdaya manusia (SDM) demikian, relasi peran lembaga pendidikan, dukungan partisipasi masyarakat dan implementasi kebijakan pemerintah masih dihadapkan pada berbagai hambatan. Permasalahan kesenjangan (inequality) dan upaya mencapai kesetaraan (equality), khususnya melalui pembangunan pendidikan, setelah dua dekade otonomi daerah rupanya sudah tidak bisa lagi sekedar mengandalkan kebijakan pemerataan akses masyarakat pada pendidikan. Baker dalam Equality: From Theory to Action memberi banyak inspirasi dalam menafsirkan makna kesetaraan. Baginya kesetaraan kondisi (equality of condition) jauh lebih penting dari kesetaraan dalam konteks akses dan partisipasi. Dalam kesetaraan kondisi fokus kita berikan bukan hanya terhadap tujuan dan proses (purposes and process) pendidikan itu sendiri, tetapi juga berkaitan dengan kesetaraan terhadap sumberdaya (equality of resources), kesetaraan dalam pengakuan dan penghargaan (respect and recognition), kesetaraan dalam kekuasaan (equality of power), dan kesetaraan dalam kepedulian, soilidaritas dan cinta (love, care and solidarity). Semua 
jenis kesetaraan ini jelas membutuhkan kecerdasan birokrasi pendidikan untuk merealisasikannya (Baker, 2004 dalam Baedowi, 2017).

Ketika kesenjangan kualitas pendidikan begitu besar antara wilayah pinggiran (periphery) layaknya wilayah pedesaan, dengan wilayah pusat (center) yang sering direpresentasikan dengan perkotaan, maka diperlukan birokrasi pendidikan yang mampu mengimplementasikan kebijakan afirmasi (affirmative action policy). Konseptualisasi kebijakan afirmasi dapat dipahami sebagai pemberlakuan kebijakan atau perlakuan yang berbeda untuk mendorong pencapaian hasil yang merata. Upaya pencapaian kondisi pemerataan ini dilakukan dengan maksud untuk mengarahkan tindakan akselerasi terhadap salah satu organ kelembagaan yang dinilai tidak se-dinamis organ lain dalam struktur kelembagaan tersebut (Sunaryo dan Cicellia, 2014).

Pada pertengahan dekade 1970an, mulai banyak kekurangan dari kebijakankebijakan yang menggunakan paradigma "pembangunisme" (developmentalism). Ketika itu E.F Schumacher berupaya meyakinkan berbagai kalangan pengambil kebijakan bahwa semestinya pembangunan dimulai dari pengembangan sumber daya manusia, bukan dari akumulasi sarana prasarana fisik. Menurutnya, orientasi utama akumulasi kekayaan adalah kesejahteraan manusia. Partisipasi masyarakat dalam pembangunan apabila diabaikan oleh perencana-perencana pembangunan, maka pembangunan apapun tidak akan berhasil. Schumacher menitikberatkan pada tiga faktor penting pembangunan, yakni pendidikan, organisasi dan disiplin. Ketiga faktor itu harus dikembangkan secara simultan, dimana tugas para aktor politik dan pengambil kebijakan pembangunan haruslah selalu berupaya mengembangkan kualitas ketiga faktor tersebut. Ketiganya harus menjadi miliki seluruh masyarakat, bukan hanya milik segolongan kecil elit saja (Schumacher, 1979 dalam Ali, 2007).

Kerangka praktek pembangunan untuk itu hendaknya berada pada dimensi penciptaan peningkatan kesejahteraan ekonomi dan sosial bagi masyarakat. Pendekatan ini memprioritaskan terbentuknya partisipasi publik, pemenuhan kebutuhan, keswadayaan, kesadaran sosial, perencanaan partisipatif (bottom-up), dan pemberdayaan masyarakat. Prinsip keterpaduan dan keberlanjutan merupakan inti pendekatan ini. Pembangunan masyarakat pada kerangka demikian diperkuat dengan asumsi bahwa pembangunan berpangkal di tingkat masyarakat bawah (grassroots level). Artinya, dalam proses peningkatan kesadaran (consciousness), masyarakat bawah digugah kesadaran mereka atas potensi yang ada dalam diri mereka. Pada tataran ideal, para anggota masyarakat dengan kapasitas SDM yang memadai mengorganisir diri mereka dalam suatu perilaku demokratis, untuk: (a) menentukan kebutuhan, permasalahan, isu-isu; (b) mengembangkan rencana dan strategi 


\section{Madekhan: "Eliminasi Kesenjangan Kualitas SDM Melalui Kebijakan Afirmasi Pendidikan di Jawa Timur"}

pemenuhan kebutuhan, dan (c) mengimplementasikan rencana yang ada dengan partisipasi sebesar mungkin dari masyarakat untuk meraup hasil-hasil pembangunan (Chamber, 1987 dalam Ali, 2007). Di tengah gejala kesenjangan sosial dan ekonomi antar lapisan dan wilayah di Indonesia, pemerintah tentu berharap adanya peran aktif dari masyarakat. Maka berbagai bentuk inisiatif dan partisipasi pelaku pembangunan non pemerintah, tentunya mensyaratkan adanya pengetahuan, keterampilan dan kesadaran. Untuk melahirkan kondisi masyarakat yang mampu mengembangkan kehidupan mereka sendiri (self relience), ketersediaan layanan pendidikan yang baik, bisa menjadi pemotong lingkaran setan kemiskinan (vicious cycle of poverty).

Adanya permasalahan kesenjangan ekonomi dan SDM antar wilayah di Provinsi Jawa Timur menjadi latar fokus kajian ini dimana dilihat dari aspek kebijakan daerah dipandangan urgen untuk adanya kebijakan afirmasi pendidikan. Dalam perspektif pengembangan SDM, kebijakan afirmasi pendidikan adalah salah satu instrumen kunci pemberdayaan masyarakat, khususnya pada wilayah, sektor atau kelompok masyarakat tertinggal. Untuk mengakomodir fokus kajian demikian maka rumusan masalah kajian ini adalah "Bagaimana skema kebijakan afirmasi pendidikan yang bisa diterapkan Pemerintah Daerah Provinsi Jawa Timur untuk mengeliminasi kesenjangan kualitas SDM antar wilayah?" Oleh karenanya tujuan kajian ini adalah untuk memformulasi prospek kebijakan afirmasi pendidikan yang strategis dan sesuai dengan kapasitas sumberdaya dan tingkat kewenangan Pemerintah Provinsi Jawa Timur. Untuk mencapai tujuan kajian, digunakan metode analisis dokumen. Menurut Bowen metode analisis dokumen adalah salah satu bentuk riset kualitatif dimana berbagai dokumen terkait diinterpretasi oleh peneliti sehingga melahirkan makna dan temuan sebagaimana tujuan penelitian (Bowen, 2009).

\section{Pembahasan}

\section{Kesenjangan Ekonomi, IPM, dan Kemiskinan}

Sampai Akhir 2019, penduduk Jawa Timur adalah warga daerah dengan perekonomian yang selalu tumbuh di atas rata-rata nasional. Badan Pusat Statistik (BPS) Jawa Timur merilis pertumbuhan ekonomi di Jatim pada 2019 mencapai 5,52 persen lebih tinggi dari pertumbuhan nasional yang hanya 5,02 persen. Namun juga harus disadari bahwa pertumbuhan ekonomi 5,52\% Provinsi Jawa Timur masih harus ditingkatkan kualitasnya. Kinerja pencapaian pertumbuhan ekonomi yang tinggi di Jawa Timur, belum dibarengi dengan capaian kinerja pengentasan kemiskinan yang masih diangka 10,37\% jumlah penduduk. Demikian pula masih diperlukan peningkatan akses pendidikan, khususnya ketika melihat angka rata-rata lama sekolah penduduk Jawa Timur 
masih 8,21 tahun, atau setara kelas dua SMP sederajat. Persandingan kinerja dua indikator kinerja kunci (key performance indicators) pembangunan Jawa Timur ini menunjukkan: Pertama Angka rata-rata lama sekolah 8,21 tahun berarti belum sesuai target Program Wajib Belajar 12 tahun yang telah dicanangkan sejak tahun 2007. Kedua, memperlihatkan bagaimana pembangunan di sektor ekonomi Jawa Timur masih menyisakan kesenjangan tingkat kesejahteraan antar wilayah dan sektor ekonomi di Jawa Timur.

Optimalnya pencapaian statistik pertumbuhan ekonomi, semestinya mempengaruhi pertumbuhan pendidikan. Dalam kebijakan pembangunan diasumsikan bahwa keberhasilan pembangunan di bidang ekonomi dapat digunakan untuk pembangunan bidang lain, termasuk pendidikan (Saripudin, 2008). Oleh karena itu, laju pertumbuhan ekonomi seyogyanya harus diiringi dengan pemerataan distribusi pendapatan sebagai dua sasaran yang sama pentingnya yang harus dicapai agar hasil-hasil pertumbuhan tersebut dinikmati oleh seluruh lapisan masyarakat (Prasetyo, 2012). Sasaran pembangunan tidak hanya berhenti sampai dengan laju pertumbuhan ekonomi yang tinggi saja seperti yang selama ini dilakukan, melainkan pertumbuhan ekonomi yang berkualitas dengan memperhitungkan pemerataan pendapatan serta pengentasan kemiskinan dan pengangguran.

Tingkat kemiskinan Provinsi Jawa Timur Meski sampai Tahun 2019, masih berada di atas rata-rata kemiskinan nasional. Namun demikian, statistik angka kemiskinan Jawa Timur setiap tahun mengalami penurunan. Di sisi lain patut dicatat bahwa meski pendapatan perkapita penduduk Jawa Timur Tahun 2019 mencapai Rp 59,25 juta dan setara dengan rata-rata perkapita nasional sebesar Rp 59,1 juta, pada 2019 hanya terdapat 5 daerah dari 38 kabupaten/kota yang pendapatan per kapitanya lebih tinggi dibandingkan pendapatan per kapita nasional. Lima daerah tersebut adalah Kota Kediri, Kota Surabaya, Kabupaten Gresik, Kabupaten Sidoarjo, dan Kota Malang. Sementara 33 daerah yang lain pendapatan per kapitanya masih lelbih rendah dari Rp 30 juta/tahun.

Ketimpangan pendapatan yang mencerminkan tingkat kesejahteraan masyarakat Jawa Timur demikian tentu berdimensi banyak masalah yang harus ditangani di Jawa Timur. Setidaknya fakta statistik tersebut mengungkapkan bagaimana diperlukan upaya kebijakan afirmasi. Pertama tentu sektor pertanian sebagai sektor penghidupan masyarakat yang paling dominan. Pemerintah Provinsi Jawa Timur hendaknya memberikan perhatian serius pada sektor pertanian, selain karena sektor ini paling banyak menyerap tenaga kerja, juga angka kemiskinan di Jawa Timur menunjukkan wilayah perdesaan sebagai kantong kemiskinan terbesar. Kedua adalah sektor industri yang mampu menjadi pengungkit pertumbuhan sektor pertanian. Kebijakan sektor 


\section{Madekhan: "Eliminasi Kesenjangan Kualitas SDM Melalui Kebijakan Afirmasi Pendidikan di Jawa Timur"}

industri semestinya berbasis pertanian di wilayah-wilayah yang selama ini masuk dalam zona pertumbuhan dan pendapatan per kapita rendah (Yustika (2011).

Permasalahan pertumbuhan ekonomi Provinsi Jawa Timur yang belum mampu menjadi daya ungkit tingkat kesejahteraan masyarakat juga tercermin dari angka kesenjangan ekonomi. Berdasarkan data Badan Pusat Statistik (BPS) Jawa Timur tercatat, tingkat ketimpangan Jawa Timur sebesar 0,36 persen pada September 2019. Dibandingkan Maret 2019, angka ini turun 0,006 poin menjadi 0,370. Angka tingkat ketimpangan pada September 2019 ini juga lebih rendah dibandingkan September 2018 sebesar 0,371 persen. Namun, bila dibandingkan secara nasional, angka ketimpangan Jawa Timur ini berada 15 besar di antara 34 provinsi di Indonesia.

Linier dengan ketimpangan ekonomi adalah pada permasalahan capaian indikator kinerja Indeks Pembangunan Manusia (IPM). Berdasarkan data pembangunan manusia dengan tolok ukur IPM, maka terlihat bahwa sampai tahun 2019 angka IPM Jawa Timur terus mengalami peningkatan. Bila pada tahun 2018 angka IPM Jawa Timur berada di angka 70,77, pada tahun 2019 meningkat menjadi 71,50 atau mengalami peningkatan 1,03 persen. Kota Surabaya adalah daerah dengan angka IPM tertinggi. Sampai tahun 2019, Kota Surabaya telah berada di angka IPM 82,22. Kesenjangan IPM di Jawa Timur ditunjukkan dengan adanya daerah dengan IPM terendah dimana tercatat di Sampang dengan IPM sebesar 61,94. Empat daerah di Jawa Timur dengan capaian IPM berkategori "sangat tinggi" adalah Kota Surabaya, Kota Malang, Kota Madiun dan Kab. Sidoarjo. Sedangkan daerah lainnya berada dalam kategori "tinggi"sebanyak 20 kabupaten/kota, dan 14 kabupaten/kota berkategori "sedang”. Sebagaimana terlihat dalam data Grafik 1 berikut ini;

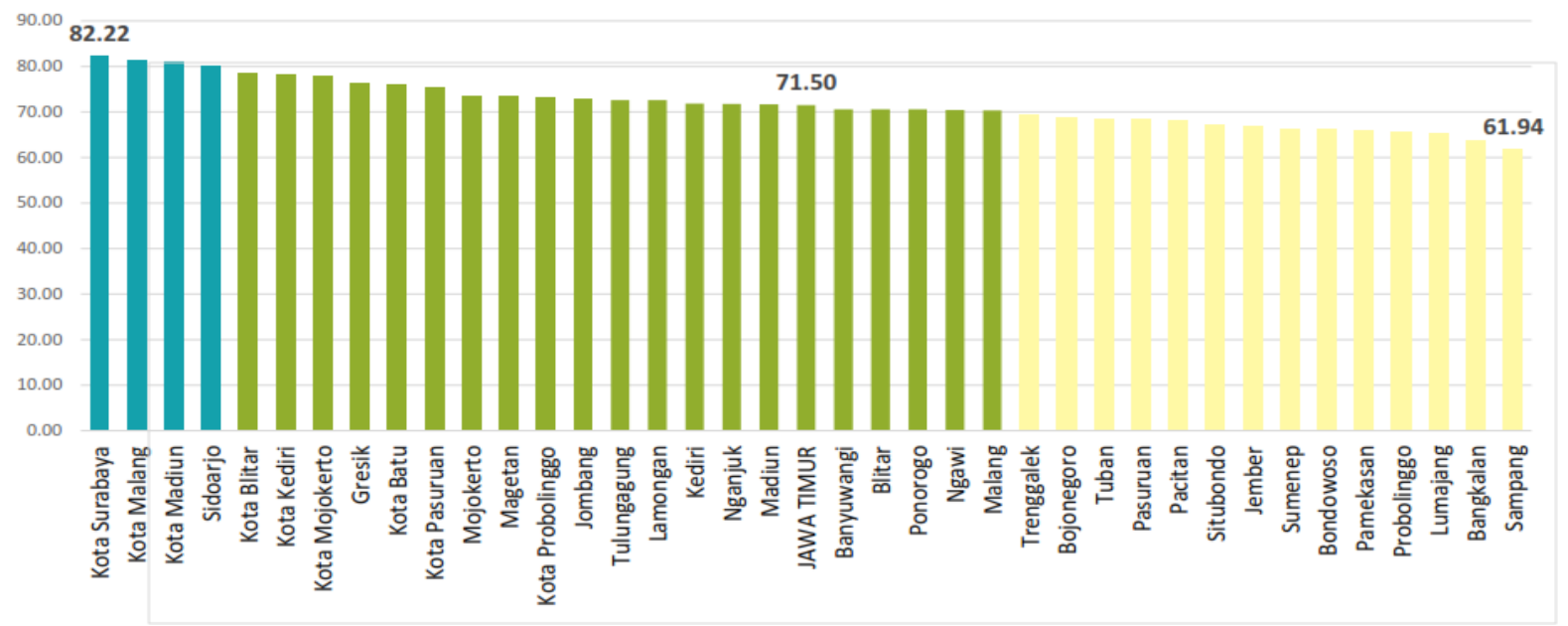

Grafik 1

Indeks Pembangunan Manusia Jawa Timur 2019 
Sumber: BPS Jatim (2019)

Sebagaimana pada Grafik 1, paling tidak terdapat 20 Kabupaten/kota di Jawa Timur dengan angka IPM lebih rendah dari rerata IPM Nasional sebesar 71,92. Terlihat pula bahwa 14 Kabupaten memerlukan kebijakan afirmasi, terutama dengan mempertimbangkan tingkat IPM yang tertinggal dari daerah lain di Provinsi Jawa Timur, maupun dari rata-rata IPM Nasional. Kondisi kesenjangan ekonomi dan IPM Provinsi Jawa Timur demikian, bisa menjadi dasar sejumlah kebijakan afirmasi strategis untuk akselerasi peningkatan IPM Kabupaten di Jawa Timur yang masih dalam kategori jauh lebih rendah dari IPM Jawa Timur maupun rata-rata nasional. Selain pertimbangan angka IPM, kebijakan Afirmatif juga dapat diberikan kepada daerah dengan tingkat kemiskinan yang masih berada di atas angka $13 \%$ jumlah penduduk.

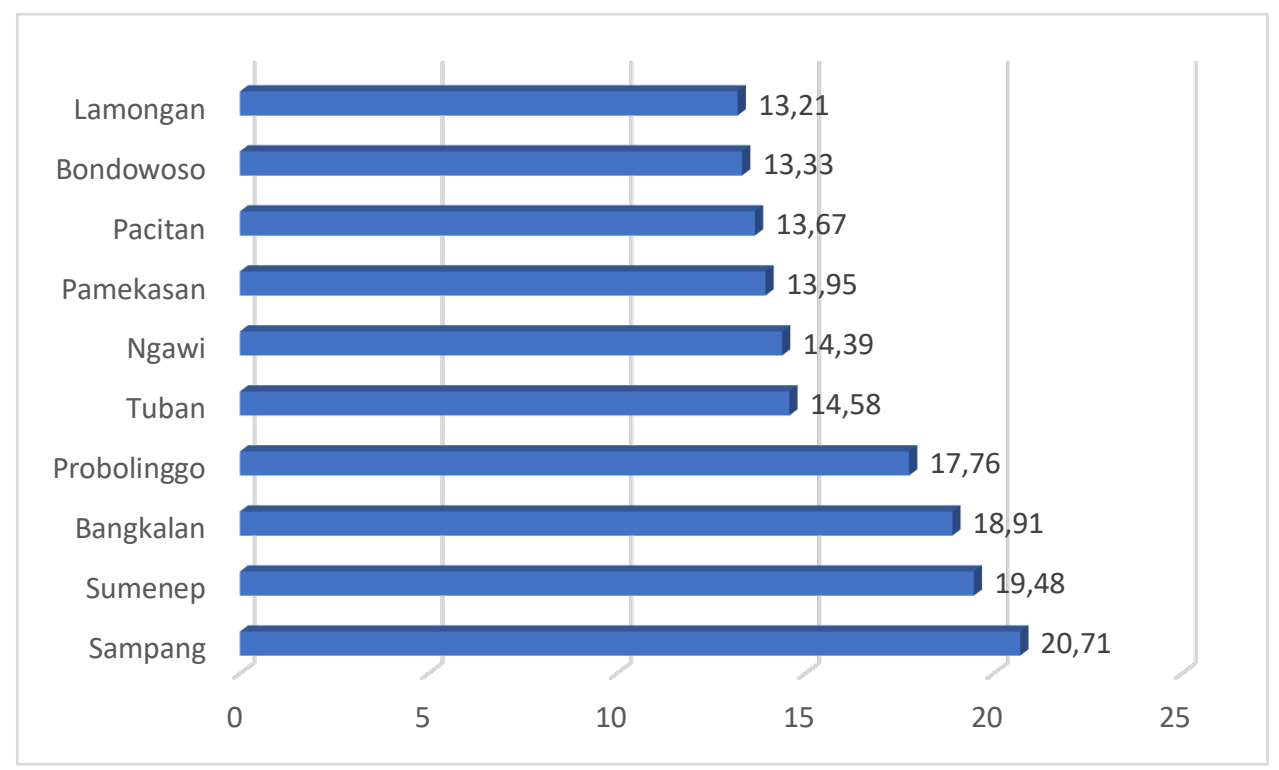

Grafik 2

10 Kabupaten Jawa Timur dengan Angka Kemiskinan di atas 13\% Sumber: BPS Jatim (2019) diolah

Tingkat kemiskinan yang tinggi di sepuluh kabupaten di Jawa Timur tersebut, cukup menggambarkan dua determinan kemiskinan yang sampai saat ini begitu nampak di sepuluh kabupaten tersebut. Mengacu pada hasil penelitian Zamhari et. al (2015), terdapat dua determinan yaitu: Pertama, sektor pertanian di Jawa Timur masih menjadi sektor yang paling berkontribusi pada angka kemiskinan. Besarnya angka kemiskinan di sektor pertanian, memiliki relasi yang kuat dengan kapasitas sektor ini dalam menampung tenaga kerja, atau dengan kata lain sebagi buffer ketika angka 


\section{Madekhan: "Eliminasi Kesenjangan Kualitas SDM Melalui Kebijakan Afirmasi Pendidikan di Jawa Timur"}

pengangguran meningkat. Gejala demikian ditunjukkan dengan bagaimana masyarakat yang bekerja sebagai petani maupun buruh tani sekedar digunakan untuk menghindari status mereka sebagai pengangguran. Anggapan umum di pedesaan adalah daripada disebut pengangguran, maka bekerja di sektor pertanian pedesaaan adalah pilihan masyarakat, walaupun dengan tingkat upah yang tidak sebanding dengan curahan waktu dan tenaga akibat keterampilan kerja yang terbatas.

Faktor kedua yang tidak kalah siginifikan dalam isu kemiskinan di perdesaan menurut Zamhari et al adalah karakteristik tingkat pendidikan kepala rumah tangga. Dengan tingkat pendidikan yang rendah, petani kepala rumah tangga dengan dengan pendapatannya yang rendah yang tidak mampu untuk memenuhi kebutuhan sehari-hari. Apalagi nilai tukar komoditi pertanian terhadap komoditi industri yang dibutuhkan keluarga petani juga cenderung menurun, menyebabkan mereka sangat sulit untuk meningkatkan kesejahteraan hidupnya. Dua determinan ini diperparah dengan adanya peningkatan investasi pertanian yang pada modal, mekanistis dan berorientasi pada komoditas ekspor. Tentu pada akhirnya terjadi penyempitan peluang lapangan kerja di sektor pertanian. Tenaga kerja di wilayah perdesaan, dengan tingkat pendidikan yang rendah, pada gilirannya terpinggirkan bekerja di sektor pekerja informal di perkotaan, maupun bertahan di desa sebagai buruh tani musiman.

Di sini terlihat bagaimana keterkaitan kemiskinan dengan pendidikan sangat besar. Kebijakan afirmatif pemerintah Provinsi Jawa Timur pada sektor pendidikan, khususnya pada daerah kantong kemiskinan di perdesaan menjadi urgen. Kebijakan pendidikan diarahkan untuk mampu memberikan kapasitas masyarakat desa untuk berkembang lewat penguasaan ilmu dan keterampilan. Premis dasarnya adalah bahwa peningkatan pembangunan modal manusia (human capital) mutlak dilakukan dalam mendorong pengembangan peningkatan produktivitas manusia. Semakin tinggi tingkat pendidikan seseorang, maka pengetahuan, keterampilan dan kesadaran atas inisiatif produktifitas hidupnya akan meningkat. Akumulasi faktor tersebut akan mendorong peningkatan produktivitas kerja dan kesejahteraan keluarga.

\section{Komitmen Afirmasi Kebijakan Fiskal}

Struktur perangkaan APBD Jawa Timur Tahun Anggaran 2020 meliputi pendapatan daerah sebesar Rp 33 Triliun dan Belanja daerah sebesar Rp 35 Triliun. Kapasitas anggaran terutama diprioritaskan untuk sektor pendidikan 30\%. Gubernur Jawa Timur, Khofifah menganggap, pendidikan menjadi ujung tombak pencetak SDM yang berkualitas. Kelengkapan kebutuhan untuk pendidikan yang menjadi tanggung jawab Pemprov Jawa Timur diarahkan untuk memenuhi dan menjamin kelancaran proses 
belajar

mengajar

(Republika,13/1/2020).

Sebagai realisasi komitmen politik semasa kampanye pencalonannya, Gubernur Khofifah menetapkan pemenuhan kebutuhan pendidikan, khususnya untuk SMA dan SMK melalui alokasi anggaran APBD 2020, khususnya lewat program pendidikan gratis berkualitas (TisTas). Penetapan 30\% APBD Jawa Timur untuk sektor pendidikan bila diukur dengan kapasitas belanja Jawa Timur tentu bisa dipandang cukup besar. Melalui komitmen Jatim Cerdas, kebijakan anggaran untuk kualitas pendidikan di Jawa Timur diharapkan mampu berdampak meningkatkan indeks pembangunan manusia (IPM).

Di sisi lain, kenyataan bahwa di balik capaian statisitik terkait tingginya pertumbuhan ekonomi, penurunan angka kemiskinan, peningkatan IPM, dan komitmen fiskal sektor pendidikan yang tinggi, permasalahan yang sering muncul kemudian adalah kinerja birokrasi sebagai implementator kebijakan. Bila ditelusuri dari kapasitas dan pengelolaan fiskal daerah maka kiranya beberapa hal harus dicatat;

Pertama, setiap tahun baik total pendapatan maupun Belanja APBD Jawa Timur terus meningkat, dan alokasi belanja hibah, bantuan sosial, bagi hasil dan bantuan keuangan ke pemerintah kabupaten/kota dalam skema program pengentasan kemiskinan juga terus bertambah. Sejak Tahun 2015, distribusi alokasi belanja hibah rata-rata di kisaran 25\%-30\% belanja daerah. Sementara Belanja Bagi Hasil dan Bantuan keuangan telah mencapai rata-rata $30 \%-35 \%$ belanja daerah. Transfer keuangan pemerintah provinsi Jawa Timur ke pemerintah Kabupaten/kota meski telah cukup proporsional, bila tidak diikuti dengan capaian kinerja pembangunan, tentu tengara yang muncul kemudian salah satunya adalah ketidakmemadaian pengelolaan anggaran transfer tersebut.

Kedua, terkait dengan relasi manajerial pemerintah Provinsi Jawa Timur dengan Pemerintah Kabupaten/Kota, problem capaian kesejahteraan masyarakat juga terkait dengan kurang optimalnya mekanisme "koreksi" atas hasil "evaluasi" tata pemerintahan. Salah satunya terkait alokasi belanja barang dan jasa yang sering mendapatkan sorotan dari masyarakat, maupun DPRD Jawa Timur. Meski setiap tahun ditemukan problem inefisiensi dan inefektifitas realisasi APBD Jawa Timur, namun sampai tahun 2019, hal tersebut belum pula mendapatkan koreksi kebijakan yang serius. Seringkali pada dokumen Laporan Keterangan Pertanggungjawaban (LKPJ) Gubernur Jawa Timur ditemukan copy paste rumusan permasalahan terkait kendala pencapaian kinerja anggaran. Hasil analisis penulis terhadap dokumen LKPJ Gubernur Jawa Timur Tahun 2009-2013 yang sampai saat ini cukup relevan sebagai pijakan implementasi anggaran pengadaan barang/jasa di Jawa Timur, sebagaimana pada Tabel 1 berikut; 
Tabel 1

Deskripsi Permasalahan Pencapaian Target Kinerja

Anggaran Pendapatan dan Belanja Daerah Provinsi Jawa Timur

\begin{tabular}{|c|c|c|}
\hline LKPJ 2011 & LKPJ 2012 & $\begin{array}{c}\text { LKPJ AMJ 2009- } \\
2013\end{array}$ \\
\hline $\begin{array}{l}\text { Penganggaran dan penetapan } \\
\text { RKA APBD, termasuk } \\
\text { APBD Perubahan, belum } \\
\text { menunjukkan ketepatsasaran, } \\
\text { khususnya dalam prosedur } \\
\text { pengadaan barang/jasa; }\end{array}$ & $\begin{array}{l}\text { Prosedur pelaksanaan } \\
\text { tahapan penganggaran dan } \\
\text { penyusunan program } \\
\text { kegiatan } \\
\text { APBD/Perubahan APBD } \\
\text { masih kurang tepat, } \\
\text { utamanya untuk kegiatan } \\
\text { lelang PBJ; }\end{array}$ & $\begin{array}{l}\text { Ketepatan waktu } \\
\text { pelaksanaan kegiatan } \\
\text { masih lemah, karena } \\
\text { perencanaan } \\
\text { pengadaan barang dan } \\
\text { jasa yang kurang tepat } \\
\text { khususnya penentuan } \\
\text { anggaran program dan } \\
\text { kegiatan. }\end{array}$ \\
\hline $\begin{array}{l}\text { Kuantitas aparatur daerah } \\
\text { yang memiliki kompetensi } \\
\text { dalam manajemen program } \\
\text { dan pertanggungjawaban } \\
\text { pelaporan APBD belum } \\
\text { merata di setiap SKPD; }\end{array}$ & $\begin{array}{l}\text { Sumber Daya Manusia } \\
\text { dari kalangan aparatur } \\
\text { SKPD masih terbatas, } \\
\text { khusunya jumlah pegawai } \\
\text { yang memiliki kompetensi } \\
\text { di bidang perencanaan, } \\
\text { penatausahaan dan } \\
\text { pertanggungjawaban } \\
\text { pelaksanaan kinerja } \\
\text { anggaran publik; }\end{array}$ & $\begin{array}{lr}\text { Output dan } & \text { hasil } \\
\text { kebijakan anggaran } & \text { perlu } \\
\text { masih } & \text { karena } \\
\text { ditingkatkan } & \text { dalam } \\
\text { rendahnya kemampuan } \\
\text { aparat } \\
\text { mengabsorbsi } \\
\text { mengadopsi berbagai } \\
\text { regulasi dan analisis } \\
\text { kebutuhan } \\
\text { dengan musyawarah } \\
\text { perencanaan } \\
\text { pembangunan daerah. }\end{array}$ \\
\hline
\end{tabular}

Berdasarkan kapasitas fiskal Jawa Timur Tahun 2019 sebagaimana data perhitungan Kementerian RI Tahun 2019, dimana telah mencapai Indeks KFD sebesar 2,589 atau dalam ketegori “sangat tinggi” Untuk eliminasi kesenjangan IPM antar kabupaten di Jawa Timur, dengan menggunakan kebijakan afirmasi fiskal daerah, maka kerangka kebijakan 
Anggaran Pendapatan dan Belanja Daerah Provinsi Jawa Timur ke depan seyogyanya diarahkan melalui pos belanja Bantuan Keuangan kepada Pemerintah Kabupaten/kota dengan skema sebagai berikut;

1. Skema kebijakan besaran anggaran Bantuan Keuangan kepada Kabupaten/kota hendaknya diprioritaskan dalam bidang pendidikan, dengan formula indikator sasaran Kabupaten/kota dengan Angka Rata-Rata Lama Sekolah di bawah 7 tahun.

2. Skema kebijakan besaran anggaran Bantuan Keuangan bidang kesehatan dengan formula indikator prioritas di Kabupaten/kota dengan Umur Harapan Hidup di bawah 70 tahun.

3. Orientasi target Bantuan Keuangan kepada kabupaten/kota diarahkan untuk mendorong tercapainya keseluruhan indikator Standar Pelayanan Minimal (SPM) pelayanan publik dasar, khususnya bidang pendidikan dan bidang kesehatan.

\section{Komitmen Kebijakan Afirmasi Pendidikan}

Sementara itu, untuk akselerasi peningkatan SDM dengan indikator IPM Jawa Timur, penulis menemukan kebijakan sektor pendidikan sebagai kebijakan afirmasi paling strategis. Pertama, kebijakan afirmasi pendidikan dalam jangka pendek hendaknya dilandaskan pada penanggulangan melemahnya daya beli masyarakat akibat Pandemi COVID-19. Sementara dalam jangka panjang maka kebijakan afirmasi tentu harus berpijak pada percepatan pencapaian target wajib belajar (WAJAR) 12 tahun di Jawa Timur dengan re-orientasi kebijakan dari dimensi akses atas pendidikan, menuju dimensi kualitas manajemen sekolah.

Pada kasus subsidi pembiayaan sekolah (school funding) contohnya, reorientasi menjadi relevan mengingat sistem pendidikan kita belum menganut asas pembiayaan sekolah secara integral. Reorientasi diperlukan khususnya bagaimana menempatkan pengembangan aspek kualitas manajemen sekolah sebagai indikator subsidi pembiayaan sekolah. Sampai saat ini, isu pembiayan sekolah bermutu (school quality funding) masih dihitung secara minimal, yaitu menyangkut besaran subsidi dari pemerintah untuk tiap siswa pada setiap satuan pendidikan. Contoh dari kebijakan ini adalah bagaimana dana Bantuan Operasional Sekolah (BOS) dari pemerintah pusat dan Bantuan Operasional Sekolah Daerah (BOSDA) Provinsi Jawa Timur dihitung. Implementasi anggaran pendidikan bersumber minimal 20\% APBN dan APBD, baru menyentuh aspek kebutuhan siswa untuk unit analisisnya tetapi belum menghitung kebutuhan institusi sekolah sebagai sebuah pendekatan penjaminan mutu (quality assurance). Pendekatan penjaminan mutu manajemen sekolah juga dimaksudkan agar tidak berlanjut inefektifitas serapan anggaran 


\section{Madekhan: "Eliminasi Kesenjangan Kualitas SDM Melalui Kebijakan Afirmasi Pendidikan di Jawa Timur"}

BOS maupun BOSDA akibat pelanggaran asas transparansi dan akuntabilitas pengelolaan subsidi pemerintah di tingkat sekolah. Disinilah penting dipikirkan kebijakan subsidi pembiayaan pendidikan dengan menggunakan manajmen sekolah sebagai unit analisis, bukan lagi kebutuhan minimal siswa.

Pergeseran orientasi perhitungan subsidi pembiayaan sekolah dari siswa sebagai unit analisis, menuju sekolah sebagai unit analisis semestinya sudah sejak lama disadari politisi dan birokrasi pendidikan. Sebagaimana kritik Coleman pada di akhir era 1960-an, bahwa dalam paradigma lama, keberhasilan siswa selalu digantungkan kepada kemampuan finansial orang tua dan karakter psikologis siswa, serta menafikan kemampuan manajerial dan budaya sekolah (Baedowi, 2017). Pembiayaan yang ditujukan untuk meningkatkan kualitas sekolah, dipandang efektif khususnya untuk menciptakan budaya sekolah yang sehat secara manajemen, dimana diyakini berdampak pada capaian akademis siswa.

Berdasarkan kapasitas fiskal Jawa Timur Tahun 2019 sebagaimana data perhitungan Kementerian RI Tahun 2019, dimana telah mencapai Indeks KFD sebesar 2,589 atau dalam ketegori "sangat tinggi" maka untuk mengeliminasi kesenjangan kualitas SDM antar daerah, kebijakan afirmasi yang bisa dilaksanakan melalui Belanja Bantuan sosial dan Belanja Hibah adalah;

1. Beban biaya pendidikan yang ditanggung masyarakat semakin tinggi, di sisi lain turunnya daya beli masyarakat akibat situasi pandemi COVID-19 menyebabkan partisipasi pembiayaan penyelenggaraan pendidikan dari masyarakat akan turun atau relatif tidak dapat ditingkatkan. Oleh karena itu alokasi bantuan sosial bersumber APBD Jawa Timur untuk kelompok rumah tangga rentan putus sekolah dasar dan sekolah menengah hendaknya diupayakan pemerintah Provinsi Jawa Timur.

2. Penetapan kebijakan tranfers fiskal daerah dalam bentuk dana bantuan pendidikan untuk lembaga penyelenggara pendidikan yang indeks kelembagaan pendidikannya di bawah indeks Standar Pelayanan Minimal (SPM). Lembagalembaga penerima transfer fiskal ini seyogyanya berada di wilayah rentan sosial, dimana kapasitas partisipasi finansial masyarakat sekitar sekolah masih rendah.

3. Pemberian insentif pendanaan untuk sekolah di area perdesaan, terpencil dan wilayah perbatasan yang mempunyai indikator kinerja baik dalam meningkatkan angka partisipasi sekolah (enrollment rate) masyarakat setempat, terkhusus lagi sekolah yang banyak mengakomodir siswa dari keluarga miskin. 
4. Penghargaan berupa tambahan penghasilan atau insentif fiskal bersumber dari APBD Provinsi Jawa Timur kepada guru-guru berprestasi dan berkomitmen mengajar di wilayah-wilayah tertinggal dan terpencil.

5. Penyusunan Basis Data Terpadu antara informasi kemiskinan dan pendidikan sebagai basis dari penetapan alokasi target siswa dari keluarga miskin.

6. Kebijakan afirmatif dalam bentuk penerbitan regulasi daerah, dimana secara prinsipil memastikan anak usia pendidikan dasar dan menengah dari keluarga miskin dapat bersekolah. Regulasi ini juga hendaknya mengatur kepastian sumber dana pendidikan bagi anak dari keluarga miskin dan lembaga pendidikan di daerah terpencil dan tertinggal.

Keenam rumusan kebijakan afirmasi tersebut setidaknya telah menyentuh isu-isu kritis pembangunan SDM melalu pendidikan saat ini: partisipasi pembiayaan masyarakat, kualitas manajemen sekolah, keterisolasian wilayah, SDM Guru, Kebijakan berbasis database pendidikan, dan komitmen regulasi afirmatif bidang pendidikan pemerintah daerah. Di dalamnya juga mengimplikasikan suatu upaya mendorong pergeseran paradigma new public management yang mewarnai pola pemikiran birokrasi pemerintah saat ini menuju new public service.

Dalam dua dekade terakhir birokrasi Indonesia telah didorong untuk mengadopsi pendekatan privat sector dalam pada sektor pelayanan publik. Kebijakan afirmasi pendidikan di Jawa Timur menuntut syarat adanya adopsi paradigma new public service yang menempatkan masyarakat sebagai pemilik pelayanan publik. Paradigma new public service (Denhardt \& Denhardt, 2003) memandang bahwa prinsip-prinsip dalam paradigma new public management yang mengedepankan indikator efisiensi, rasionalisasi, produktifitas dan bisnis pada birokrasi pemerintahan. Kerangka prinsip pemerintahan demikian menurut Denhart tidak mendukung nilai-nilai kepentingan publik dan demokrasi. Alasan Denhardt, dalam new public service maka secara filosofis harus diyakini bahwa pemilik kepentingan publik hakikatnya adalah masyarakat (public). Oleh karena itu aparat birokrasi harus menjalankan pelayanan pemerintahan dengan memusatkan pada akuntabilitas pelayanan kepada setiap warga negara (Denhardt dan Denhardt, 2003 dalam Haryono, 2012).

\section{KESIMPULAN}

Untuk mengeliminasi kesenjangan kualitas SDM antar wilayah di Jawa Timur diperlukan kebijakan afirmasi sesuai dengan kapasitas sumberdaya dan lingkup kewenangan Pemerintah Provinsi Jawa Timur. Berdasarkan tingkat kapasitas fiskal 


\section{Madekhan: "Eliminasi Kesenjangan Kualitas SDM Melalui Kebijakan Afirmasi Pendidikan di Jawa Timur"}

daerah dalam kategori tinggi, prospek diskresi kebijakan afirmasi pendidikan oleh Pemerintah Provinsi Jawa Timur dapat melalui tiga jalur. Jalur pertama adalah kebijakan transfer anggaran pada pos belanja Bantuan Keuangan kepada Kabupaten/kota. Jalur kedua melalui Bantuan Hibah yang langsung ditransfer ke rekening sekolah, dan jalur ketiga melalui regulasi yang menjamin mutu sekolah di daerah terpencil. Jalur kebijakan afirmasi belanja Bantuan Keuangan hendaknya diberikan kepada pemerintah daerah dengan angka kemiskinan Kabupaten/kota di atas 13\%, angka IPM di bawah 70, Angka Rata-Rata Lama Sekolah di bawah 7 tahun, dan Umur Harapan Hidup di bawah 70 tahun. Sedangkan jalur Bantuan Hibah diberikan kepada sekolah-sekolah dengan indikator ketertinggalan indeks SPM, keterisoliran wilayah, dan kebutuhan insentif guru berprestasi di wilayah terpencil. Untuk efektifitas kebijakan afirmasi maka diperlukan jalur kebijakan regulasi penjaminan mutu pendidikan di daerah tertinggal atau terpencil.

\section{Daftar Pustaka}

Ali, Madekhan. (2007), Orang Desa Anak Tiri Perubahan, Malang, Averroes Press

Baedowi, Ahmad. (2017) "Nilai-Nilai Dasar Sukma Bangsa”. Jurnal Pendidikan Sukma 1(1): $1-18$

BPS, Jawa Timur. (2020), Berita Resmi Statistik Februari 2020, BPS Jawa Timur

BPS, Lamongan. (2019), Profil Kemiskinan Kabupaten Lamongan Maret 2019, BPS Lamongan

Bowen, G. A. (2009). Document analysis as a qualitative research method. Qualitative Research Journal, vol. 9, no. 2: 29-40

Denhardt, Robert B. Denhardt. Janet, V. (2014) The New Public Service: An Approach to Reform, Taylor \& Francis Online Website, [diakses 1 Juli 2020], https://www.tandfonline.com/doi/abs/10.1080/12294659.2003.10805013

Gubernur Jawa Timur (2014) Laporan Keterangan Pertanggungjawaban Akhir Masa Jabatan Gubernur Jawa Timur Tahun Periode 2009 - 2014.

Gubernur Jawa Timur (2015) Laporan Keterangan Pertanggungjawaban Akhir Tahun Anggaran, Pemerintah Provinsi Jawa Timur

Haryono, Nanang. (2012) “Jejaring Untuk Membangun Kolaborasi Sektor Publik”, Jurnal Jejaring Administrasi Publik, Th IV. Nomor 1: 47-53

Meents, Miranda. (2010), How Education Changes The World, University of British Columbia website, [Diakses 9 Juni 2020], https://www.grad.ubc.ca/aboutus/initiatives-plans-reports/how-education-changes-world 
Prasetyo, Eko. (2012), “The Quality Of Growth: Peran Teknologi Dan Investasi Human Capital Sebagai Pemacu Pertumbuhan Ekonomi Berkualitas”. Jurnal JEJAK, Volume 1, Nomor 1: 45-56

Peraturan Menteri Keuangan Republik Indonesia Nomor 126/PMK.OL/2019 Tentang Peta Kapasitas Fiskal Daerah.

Saripudin, Didin. (2008) Pembangunan Pendidikan Dan Pertumbuhan Ekonomi Indonesia, Makalah disajikan dalam International Seminar on Lifelong Education (ISLE), Tanggal 22-23 Agustus 2008 di Universitas Pendidikan Indonesia, Bandung. [Diakses 8 Juli 2020] http://sejarah.upi.edu/artikel/dosen/pembangunan-pendidikan-danpertumbuhan-ekonomi-indonesia/

Sunaryo, Bambang, Cicellia, Celly. (2014) "Nilai Penting Konsep Affirmative Action Policy Dalam Pengembangan Sumber Daya Manusia (Sdm) Aparatur Berbasis Merit” Jurnal Kebijakan dan Manajemen PNS VOL. 8, No.1: 112

Yustika, Ahmad, E. (2011) Rapor Buram Ekonomi Jatim, ahmaderani.com Website, [diakses 9 Juni 2020], https://ahmaderani.com/rapor-buram-ekonomijatim.html/2

Zamhari, J. Wisadirana, D. Kanto, S. (2015) “Analisis Determinan Kemiskinan di Jawa Timur” Jurnal Wacana, Vol. 18, No. 1: 41-50 